\title{
Handling of Florida-grown and Imported Tropical Fruits and Vegetables
}

\author{
Craig A. Campbell \\ EcoScience Produce Systems Corporation, P.O. Box 3228, 4300 LB McLeod Road, Orlando, FL 32802
}

South Florida has become an important trading and distribution center for tropical fruits and vegetables in the United States. Production of tropical crops in South Florida increases each year, both in volume and number of species. The presence there of a viable young industry producing dozens of tropical commodities, coupled with South Florida's proximity to Central and South America and the Caribbean, have made the area attractive to foreign and domestic producers. The seaports of Miami, Fort Lauderdale, and West Palm Beach provide reliable service for importers, while several international airports in the area meet the needs of shippers moving highly perishable products. Shipping, handling, and selling imported fruits and vegetables keeps fruit companies on Florida's southern tip busy in the off-season. The imported products are a welcome addition to the large group of fruits and vegetables produced locally. In the case of mangos, fruit are imported throughout the fall and winter from the tropics, but not in the summer when local fruit is available.

Phytosanitary regulations are a vital consideration for trading companies bringing tropical fruits and vegetables to the United States. Quarantine restrictions can render some trading schemes unattractive or at least compel producers in foreign countries to form various associations that allow for a unified voice when dealing with the U.S. government. Many of the U.S. Dept. of Agriculture regulations stipulate that the foreign producer must take the lead role in efforts to bring products here, although companies in South Florida are encouraged to assist their foreign trading partners whenever possible.

Losses during handling and marketing these new products are often high. Long transit times from production areas, unfamiliarity with the commodity on the part of handlers and marketing firms, and the lack of adequate equipment or technology to accommodate the fruits and vegetables contribute to postharvest losses that at times exceed $50 \%$ of a given shipment. Interaction between postharvest biologists in the research community and the private sector can allow vast improvements in tropical fruit and vegetable handling systems. All too often a U.S. consumer's first introduction to a bright red, Peruvian mango purchased in New York during the winter is disappointing because the fruit, when cut in the home, is tasteless and rubbery from being harvested prematurely to accommodate the long marketing chain. A mango produced in Peru's northern desert may take 20 days or more to reach a retail market if shipped by sea. While 20 days may represent the outside limit of a mango's postharvest life, many shipments have been successful with the proper sanitation and temperature management. Refrigerated transport containers, fitted with equipment for controlling the storage atmosphere, are being tested to control mango ripening and decay during long sea voyages. All parties involved should cooperate to improve handling systems, thus improving product quality and encouraging customer acceptance of these new tropical commodities.

\section{SOUTH FLORIDA'S PRODUCTION}

Production of fresh-market avocados and limes formed the basis for the tropical fruit industry in South Florida. These two fruits still lead all others in production volume, but each has its own set of postharvest problems that limit storage and marketing. The popularity of mango has exploded recently, with dramatic increases in U.S. imports and renewed excitement among South Florida growers leading the way to a more competitive, professional industry. The increased production of carambola, lychee, longan, passionfruit, atemoya, kumquat, pummelo, guava, and various other fruits grown on South Florida farms has made an impact on tropical fruit availability throughout the United States. In this section, production trends that relate to a particular fruit's status in the industry will be discussed along with information about current and potential handling methods.

\section{Avocado (Persea americana Mill.)}

The varieties grown in Florida are numerous and widely variable. Early varieties are usually of West Indian origin, whereas midseason and late varieties are hybrids of West Indian and Guatemalan parentage having intermediate characters. Early varieties usually are light in color, ripen rapidly, and have a low oil content. Varieties that mature early in Florida's season are less popular with consumers, tending also to be more chilling sensitive. Florida producers grow numerous varieties to maintain a long harvest season. They realize that early season fruit must be handled carefully to protect fast-ripening avocados from bruising and chilling injury. Later in the season, fruit are held at lower temperatures, $5 \mathrm{C}$ compared with 7 to $13 \mathrm{C}$ for early fruit, and stored longer (Hatton and Campbell, 1965). The introduction of hydrocooling in avocado packinghouses in the 1970s provided a method for rapidly and consistently removing field heat, which allows longer storage and safer transport of avocados throughout the season.

\section{'Tahiti' lime [Citrus aurantifolia (L.) Swingle]}

This fruit, although having a thick rind and low respiratory rate, is difficult to handle. The fact that limes are chilling sensitive, yellow rapidly, and prone to serious physiological disorders make them worthy of further study. Stylar end breakdown (SEB), a disorder promoted by high fruit turgor and high temperatures, develops when juice vesicles rupture in a fruit, releasing juice that kills albedo and flavedo cells, starting at the stylar end, and quickly causes the fruit to spoil (Campbell, 1979; Phillips and Goldweber, 1981). The problem must be continuously managed by Florida producers to avoid harvesting in times when turgor pressure is high in the tree and fruit. The practicality of harvesting only when trees have low turgor is questionable when faced with the rainy, hot, South Florida summers occurring when limes are most abundant. Large companies use pressure testers in the field to avoid SEB by measuring fruit turgor, a practice researchers suggested after determining that fruit can be safely harvested when more than $\approx 18 \mathrm{~N}$ force is required to rupture oil glands on the fruit surface. Even though the method is simple and the results immediate, many growers are reluctant to adopt the techniquefearing lost labor hours and increased costs. In the packinghouse, fruit are often held for $24 \mathrm{~h}$ before packing to allow SEB development so that affected fruit can be detected during grading. Oleocellosis is a less important disorder, also influenced by fruit turgor, that occurs throughout the season in response to rough handling. Fruit with oleocellosis have areas on the flavedo where cells have collapsed and turned brown, which makes the fruit unattractive but usually does not lead to decay.

Yellowing of harvested limes is a tremendous problem to producers and retailers. Many receivers reject shipments that are "too yellow." Low-temperature storage cannot be used to slow yellowing because limes are chilling sensitive and should not be stored below 12C. Hypobaric storage, plant growth regulators, and various other methods have been explored to prevent degreening of limes; most methods have had very limited success due to erratic results or commercial impracticality. Postharvest coatings seem to be the simplest and most reliable method to prevent degreening. Coatings decrease the rate of water loss from the fruit and delay senescence of the rind by creating a modified atmosphere. Various commercial waxes and oils will help delay yellowing of limes and maintain a superior fruit appearance.

\section{Mango (Mangifera indica L.)}

Handling methods for this tropical fruit are geared toward controlling ripening and fungal diseases. Anthracnose, caused by 
Colletotrichum gloeosporioides (Penz.) Sacc., is the most important disease of mango fruit in Florida. Diseased mangos are removed in the packinghouse during the grading process; however, the pin-point anthracnose lesions are difficult to detect on unripe fruit. These small fungal spots will enlarge during ripening and rapidly rot a fruit. For this reason, anthracnose decay is seldom a problem until after fruit are shipped and placed in stores or in a consumer's home. Ripe mangos with anthracnose decay have large, smooth, black spots that eventually coalesce, covering most of the fruit surface. Postharvest control measures retard anthracnose development on fruit that were previously infected in the field.

The other major postharvest disease is stem-end rot, caused by Diplodia natalensis P. Evans. Stem-end rot is particularly troublesome in immature and early season fruit. On prematurely harvested mangos, stem-end rot often begins before fruit ripening and progresses quickly. The stem area of an infected fruit turns light brown, soft, and watersoaked. Hot-water dips are effective in controlling anthracnose and, to a lesser degree, stem-end rot (Smoot and Segall, 1963; Spalding and Reeder, 1972). Treated mangos are submerged in water maintained at 53 to $55 \mathrm{C}$ for 3 to $5 \mathrm{~min}$, depending on the variety and maturity stage. Research on the combination of fungicides and hot water has been promising. South Florida companies are working with the appropriate agencies to register the fungicide 1-[2-(2,4-dichlorophenyl)-2-(2propenyloxy)ethyl]-1 $H$-imidazole (imazalil) for use in hot-water tanks; the work, however, is not yet complete.

Mango ripening is controlled using temperature management and exposure to ethylene. Ripening is promoted in early season fruit, contrasted with later in the season, when fruit ripening is purposely delayed to facilitate storage and transport. Ethylene (10-20 ppm) is applied early in the season to mature, unripe fruit, held at $21 \mathrm{C}$ and high humidity, to promote uniform ripening and superior color development. Various time-temperature regimes are used, depending on the variety and its maturity stage. All ethylene gassing is stopped late in the season, when fruit are stored at 10 to $12 \mathrm{C}$ after hot-water treatment and packing.

A new handling practice has recently gained popularity in South Florida. One large mango packer is packing tree-ripened fruit, which in the past were removed as culls. They are handled carefully, placed in decorative paper cups, and sold in single-layer boxes as a new product line. The special mangos are harvested separately in plastic crates and packed by hand on a small packing line. These full-color mangos are very attractive and flavorful, but will bruise easily, are prone to decay, and must be sold quickly. The ripe mangos will tolerate cooler temperatures and are transported at 8 to 10C. "Tree-ripes" are sold throughout Florida, but they are also put on direct trucks to customers as far away as New York, where many people prefer the ripe fruit.

\section{Carambola (Averrhoa carambola L.)}

No fruit typifies the growth of South Florida's tropical fruit industry better than carambola. An industry-wide volume just 5 years ago of 70 t or less increased to $\approx 2000 \mathrm{t}$ in 1991 . Handling methods have changed to suit increased volume and storage requirements. The optimum storage temperature for carambola harvested at color break is $5 \mathrm{C}$, a low temperature for a tropical fruit but convenient for handlers because carambolas can be combined with avocado shipments (Campbell et al., 1987). Carambola fruit have a low respiratory rate and are not adversely affected by ethylene, nor are they a copious ethylene producer (Campbell et al., 1989). The primary storage disorders in carambola are texture changes and browning on the fin margins due to water loss. Bruising, which leads to browning and decay, is another major concern. Carambola fruit can be stored for several weeks if packed carefully and protected from desiccation. Wrapping fruit in waxed tissue and, more recently, coatings have been used for preventing water loss. Despite the dramatic increase in production, carambolas are still harvested in plastic field crates and packed directly from the crates into a carton designed for storage or shipping. More automated methods for sizing, grading, and packing this tender commodity have eluded producers. Washers and hydrocoolers, which accommodate the harvest crates, are now being used along with coating applicators that dip and drain the fruit in the same crates. Automated carambola packing has involved more rapid delivery of the harvest container, packing supplies, and corrugated cartons to the packers, combined with efficient removal of cull fruit. Rapidly hydrocooling fruit to $5 \mathrm{C}$ is anticipated to reduce problems with desiccation.

A cooperative effort a few years ago between the U.S. Dept. of Agriculture (USDA), a private carambola packer, and the states of Florida and California resulted in the development of a cold treatment (15 days at $1.1 \mathrm{C}$ ) that provides quarantine security against Caribbean fruit fly (Anastrepha suspensa Loew), a pest endemic in South Florida but not found in California. The USDA-developed treatment was adopted by the Florida Dept. of Agriculture and accepted by California's plant quarantine division for use on shipments of carambola fruit. Later, the Arizona authorities accepted the 15-day quarantine treatment. As with all quarantine methods, companies using the treatment must carefully monitor temperature, record data, and handle fruit to prevent misuse and potential reinfestation. The treatment has been successful for the South Florida industry-shipments of treated fruit sometimes have exceeded $380 \mathrm{t}$ since the program's inception. Quality problems associated with treated fruit have been few; occasionally, shriveling and fruit browning occur due to desiccation or chilling injury, especially in early season fruit.

\section{Lychee (Litchi chinensis Sonn.) and longan (Dimocarpus longan Lour.)}

Lychee and longan production in South Florida is increasing, with producers forecasting a strong U.S. market that will become increasingly competitive due to the large plantings of young trees that have not yet achieved peak production. Handling methods for lychee, and the closely related longan, are designed to prevent desiccation and protect the fruit from crushing. Fruit in South Florida are rarely kept more than $24 \mathrm{~h}$ before shipment because oxidative browning of the pericarp (skin) can develop overnight in unprotected fruit. Storing fruit at 5 to $7 \mathrm{C}$ in boxes lined with vented polyethylene bags will greatly retard browning (Hatton et al., 1966), but shippers must be careful when shipping this fruit by air. Fruit that have been cooled previously and placed in bags will often rot during or after air transport because of condensation within the bags. Many lychee buyers do not have adequate cooling facilities or the means to properly handle the fruit. Many producers leave the fruit in large bunches (panicles), ship only by air, and never cool the fruit. Large companies that sell to retail grocery chains remove the fruit from the panicles and cool them before packing, use boxes with vented liners, and transport them by truck at 5C. Longans are packed similarly, except that they are left in small bunches containing a few to about 12 fruit. Work related to fruit sanitation and postharvest treatments to retard browning is being undertaken. Handling methods used in Australia-fruit dips in hot water plus benomyl-reduce decay, but these fungicide treatments are not permitted in the United States.

\section{Passionfruit (Passiflora edulis Sims)}

The production of passionfruit is one of the newest endeavors in the South Florida industry. Few handling methods have been developed locally to accommodate the 40 to $50 \mathrm{t}$ of fruit produced for the freshfruit market. Diseases are the largest obstacle to increased production. No postharvest fungicides are available to combat the numerous pathogens that cause fruit rots. It is not surprising that several pathogens causing postharvest rots have been identified when one considers that the fruit are collected from the ground, after natural abscission. Fruit are typically washed in chlorinated water, graded to remove diseased fruit, and packed in plastic cell-trays that are put inside cartons. Producers have gained a special-use label for one preharvest fungicide and hope to develop better methods for treating fruit after harvest. Good results were obtained when mature fruit were clipped from the vines (before natural abscission) and treated with ethylene to promote ripening. The treatment, although effective in providing fruit with less disease and a better postharvest life, was very labor intensive for harvesters. 


\section{Atemoya (Annona cherimola $\mathbf{x}$ Annona squamosa) and guava (Psidium guajava L.)}

Ripening control is the goal of atemoya and guava producers in South Florida who want to expand the current market for these fastripening fruits. Both of these climacteric tropical fruits are chilling sensitive and have high respiratory rates. Atemoyas are generally cooled to $12 \mathrm{C}$ immediately after harvest, packed in single-layer flats, and sold by count, not net weight. Guavas, in contrast, are cooled and then packed in cartons holding $4.5 \mathrm{~kg}$. Much can be done to improve the current handling practices for these two fruits; guavas, for example, respond very favorably when encased in a semipermeable coating to retard ripening. Atemoya fruit are more difficult to manage. To develop a good flavor and texture when soft, atemoyas must be harvested late in their development. When harvested in this manner, however, fruit will ripen in 1 to 4 days; little can be done to retard the ripening rate. Atemoya fruit tend to split around the stem as they soften, making them prone to fungal invasion. Fruit in South Florida have not responded well to modified-atmosphere packaging and quickly ferment even in the most permeable packages. Forced-air cooling and hydrocooling appear to be promising methods to remove heat quickly from these fruit to facilitate storage and transport. Consumer demand for these two fruits is good, and production will increase if successful handling methods can be developed.

\section{Other tropical fruits}

More than a dozen other tropical fruits are commercially produced in South Florida; some have a great potential for expanded production. The species mentioned so far are the primary fruits grown in the area. Other fruits are likely to gain importance as some of today's popular items lose favor. Mamey sapote [Pouteria sapota (Jacq.) H.E. Moore \& Stearn] deserves mention, as it is a fruit with relatively high production $(>20 t)$ and good potential in specialty markets. It was not mentioned previously because production has actually decreased in response to freezes in South Florida and weak demand. It is a chillingsensitive fruit but can be stored and shipped successfully by truck to northern markets. Kumquat (Fortunella sp.) and pummelo [Citrus grandis (L.) Osb.] are two other crops with expanding production. Handling methods for them have been taken from the wealth of knowledge available in the state for fresh-market citrus.

Modified-atmosphere storage techniques have shown promise in delaying fruit ripening in many tropical species for extended storage or simply to allow shipping riper fruit to retailers (Kader et al., 1989). Many retailers are expressing an interest in selling fruit that is ripe, or nearly so, to satisfy customers' need for ready-to-eat and more flavorful fruit. Producers are responding to this interest but are discovering the added complexities involved when handling riper fruit. Many produce handlers are unaware of the primary differences in ripe vs. unripe fruit in regards to respiratory rates and production of vital heat, ethylene, and $\mathrm{CO}_{2}$.

Fruit companies in the area do much of their own marketing and market research. Handling practices for the crops are either devised by the companies or through an important cooperative system with state and federal research agencies. Members of the South Florida industry, out of commitment and necessity, have developed handling methods for many tropical fruits previously unknown in the United States.

\section{Tropical vegetables}

Tropical vegetable production in South Florida is dominated by small companies that use vastly different methods for washing, cooling, and packing produce. Cassava, (yuca, Manihot esculenta Crantz), malanga [dasheen, Xanthosoma sagittifolium (L.) Schott], and boniato [Ipomoea batatas (L.) Lam.] production changes in magnitude depending on the previous year's weather and market prices. A year of high production and low prices dissuades many growers from replanting. Generally, cassava and malanga are washed by hand or in brushwashers and then packed in cartons holding $23 \mathrm{~kg}$. Chlorination, if used, is usually inadequate in washers, contributing to serious decay problems. Air driers, similar to those used for potatoes, can improve product quality by rapidly drying the products after digging and washing. Boniato, a tropical sweetpotato grown in the area, is not cured because buyers think this adversely affects the product's texture. As a result, postharvest rots are sometimes severe. Sweetpotatoes are dug, washed, and packed in burlap bags. They are sometimes repacked in cartons for grocery-chain customers to facilitate stacking and further handling. These starchy crops are stored at moderate temperatures, 10 to $15 \mathrm{C}$. Although most companies do not control the relative humidity within storages, storage in a dry atmosphere reduces postharvest rots.

Another group of tropical vegetables, collectively referred to locally as "Asian vegetables," are grown in the area and sold nearby, with some production being shipped to markets in other states. Several types of cucurbits and legumes dominate this group, along with a few spices. These products, in general, do not enter the large-volume commercial market and therefore will not be discussed in more detail.

\section{IMPORTED TROPICAL FRUITS AND VEGETABLES}

The most successful produce companies in South Florida have learned that valid technical support for their growers is essential. Harvesting guides for pickers, complete with color photos, have been used to prevent the harvest of immature carambola fruit in South Florida. Growers greatly appreciate the support and repay the company with their loyalty and commitment to quality improvement.

This same technical support is used to advise foreign producers entering the U.S. market. Many relationships exist where the U.S. firm has no involvement with the importing company, other than to take delivery of the product and provide payment. Technology transfer to foreign producers, however, can prevent many potential problems and make for a lasting trade relationship with fewer problems. Knowledge of import regulations, postharvest treatments, and packing and shipping methods are provided to the importer and tailored to suit local conditions.

\section{Mango}

Many countries in Central and South America and the Caribbean have been recently approved to ship hot-water-treated mangos to the United States. The interest expressed by several nations in the area to start treating and shipping fruit has set into motion a remarkable increase in new orchards, often without the support of a treatment facility. Countries with existing mango orchards and established packing companies obviously have a distinct advantage. They simply add the United States as a customer along with the European market. Competition has already increased markedly between Brazil, Ecuador, Peru, and Venezuela, the prominent producers sending fruit to the United States during our winter months. Mexico, one of the world's leading mango producers, ships fruit to the United States during the same summer period as Florida's season, while Haiti has been prohibited entry by the United States for political reasons.

Hot-water treatments, designed to safeguard against several fruit fly species, vary according to mango variety and fruit mass, but all involve complete submersion of the fruit in water maintained at $46.1 \mathrm{C}$ for $\geq 1 \mathrm{~h}$. Information concerning specific treatments in a given area can be easily obtained from the USDA. New treatment schedules are being developed for large mangos from some areas. Treatment installations must pass inspections by U.S. officials who also must be present at all times fruit are being treated. The importing country is required to support a new import venture with appropriate representation by their government officials, technical support, and record keeping. Funding, which may come from private sources, must be supplied to the USDA to cover operating costs for the U.S. inspectors and the program.

Because hot-water treatment is a common thread connecting all imported mangos, it is the central feature of a handling system. Harvesting, cooling, packaging, and container loading must accommodate the demands imposed by the phytosanitary regulations. Fruit cannot be cooled below $21 \mathrm{C}$ immediately after treatment, and, similarly, no treatment can commence unless fruit are $21 \mathrm{C}$ or warmer. To prevent reinfestation, fruit are packed and containers loaded only in 
areas protected by screening. Mangos will not tolerate long hot-water treatment unless they are fully developed. The treatment will scald fruit that is picked too early. The fruit may begin to show symptoms within hours, or may appear undamaged at first, only to shrivel and rot as much as 1 week later. Fruit harvested close to ripeness and then treated, however, will probably not survive a sea voyage lasting 1 to 2 weeks. Generally, fruit are harvested when fully expanded, having flesh that is one-half yellow or more, but still firm. Fruit that is airshipped obviously can be picked at a later maturity stage. Most fruit produced in Ecuador and Peru is sized, graded, and packed by hand without the aid of packing lines. Some packinghouses in Brazil have automated packing lines to handle fruit after treatment. Not all producers have cooling facilities for their mangos, relying instead on inadequately refrigerated trailers for cooling, or simply the prompt export of their product to prevent fruit ripening. The standard export carton holds $4.5 \mathrm{~kg}$ of fruit and is designed to be hand-folded instead of machine-glued or stapled. Mango shipments from Central and South America have arrived in the United States with mixed quality. Scalded and shriveled skin, internal damage, and over-ripeness are the prominent problems in imported mangos. Producers are learning to minimize these problems with careful attention to fruit maturity and temperature management during packing and transport.

\section{Papaya (Carica papaya L.)}

South Florida companies import high-quality, red-fleshed papayas from the Caribbean and Central America. Jamaica, Belize, and Costa Rica are the primary producers of the solo papayas, with 'Sunrise' being the principal variety. The fruit are packed in single-layer boxes that are sold by count. Most companies wrap fruit individually in paper, but a few use foam sleeves that cover each papaya in the box. Most shipments from Jamaica are sent by air freight, but sea shipments are becoming more popular. Most fruit from Belize is sent in sea containers maintained at 10 to $12 \mathrm{C}$. Most shipments have been received in good condition. The papayas grown in Belize are handled by a single company that hand-packs all fruit in a small packinghouse without automated machinery. The fruit are washed by hand, packed, and loaded into sea containers for the 4-day voyage. Some Jamaican producers use automatic sizers and conveyors for grading and packing. Postharvest decays are the principal problem in the papaya shipments, sometimes affecting $25 \%$ or more of the fruit. Some producers treat fruit with 2-(4-thiazolyl) benzimidazole (thiabendazole) to reduce decay. Other major quality problems include fruit that arrive ripe and soft due to delays during transport, or fruit that simply ripen too fast during periods of exceptionally hot, rainy weather.

Other tropical fruits, such as key limes [Citrus aurantifolia(Christm.) Swingle] from Guatemala and specialty bananas (Musa spp.) from Colombia, are traded in smaller volumes; yet they form a valuable part of a company's product line. Each crop mentioned in this paper was, at one time, a low-volume specialty fruit.

\section{Tropical vegetables}

Central American countries have been shipping tropical vegetables to South Florida for many seasons, but the volume of this trade has increased recently. Chayote [Sechium edule (Jacq.) Sw.], yuca, malanga, and eddo [Colocasia esculenta (L.) Schott] are shipped in entire trailer loads for distribution in the United States. Chayote, a light-green, pearshaped squash, sometimes called vegetable pear or trellis squash in the United States, is shipped in the largest volume. It is tender and must be handled carefully to avoid bruising and abrasion. The squash are wrapped individually in tissue paper or placed in plastic bags; however, the bags are considered inferior because they allow water to accumulate, thus increasing decay problems. Chayote squash are generally sold in 24 -count cartons that weigh $\approx 6 \mathrm{~kg}$. The most common storage temperature for chayote is 5 to $7 \mathrm{C}$. Several pathogens cause stem-end rot of chayote, representing the most serious disease problem. A disorder, characterized by water-soaked blisters on the chayote's surface, sometimes affects a large percentage of a given shipment. This curious disorder usually occurs during periods of rainy weather and is made worse by handling the squash roughly.

Calabaza (Curcubita pepo L.), a tropical pumpkin, is shipped in large net bags holding $\approx 23 \mathrm{~kg}$. The pumpkins are harvested by hand, washed, packed in bags, and shipped in bulk containers to the United States. Bacterial decays are prevalent when pumpkins develop during rainy weather. Infection occurs in the field, and often a large percentage of the pumpkins are rotted when unloaded at the U.S. destination. Careful sanitation and handling the fruit gently reduce decay, but few producers are willing to invest in better handling methods because calabaza is not a high-value commodity.

Yuca, malanga, and eddo are starchy vegetables that are handled in nearly the same manner after harvest. They are simply removed from the soil, washed, and then packed in cartons holding $23 \mathrm{~kg}$. Modifying handling methods can improve product sanitation, drying, and cooling. Fungal decays and sprouting are the most serious quality problems associated with these commodities. Rapidly drying the washed products would reduce decay problems and discourage sprouting. Heated drying tunnels have been installed in a few locations for this purpose. Coating freshly harvested yuca roots with paraffin after washing greatly preserves their market quality by reducing a disorder known as vascular streaking. This coating system involves melting blocks of pure paraffin in electrically heated tanks into which washed and dried roots are dipped by hand. The wax seal must be complete to ensure the proper protection of the root. Properly coated roots will have a smooth coating that is completely clear. A whitish, cloudy coating indicates that the roots were too wet or the wax too cold during dipping. Postharvest treatments focusing on sanitation are the most important concern in tropical vegetable packinghouses.

In this paper, I have attempted to describe the handling practices used for several important tropical commodities in the U.S. market. Most of these crops are new to North American consumers and produce handlers. Trade in these products seems certain to increase in the future as U.S. consumers become better acquainted with tropical fruits and vegetables.

\section{Literature Cited}

Campbell, C.A., D.J. Huber, and K.E. Koch. 1987. Postharvest response of carambolas to storage at low temperature. Proc. Fla. State Hort. Soc. 100:272-275.

Campbell, C.A., D.J. Huber, and K.E. Koch. 1989. Postharvest changes in sugars, acids, and color of carambola fruit at various temperatures. HortScience 24:472-475.

Campbell, C.W. 1979. Tahiti lime production in Florida. Inst. of Food and Agr. Sci., Univ. of Florida Bul. 187.

Hatton, T.T., Jr, and C.W. Campbell. 1965. Ripening and storage of Florida avocados. U.S. Dept. Agr., Agr. Res. Serv. Mktg. Res. Rpt. 697.

Hatton, T.T., W.F. Reeder, and J. Kaufman. 1966. Maintaining market quality of fresh lychees during storage and transit. U.S. Dept. Agr., Agr. Res. Serv., Mktg. Res. Rpt. 770.

Kader, A.A., D. Zagory, and E.L. Kerbel. 1989. Modified atmosphere packaging of fruits and vegetables. CRC Crit. Rev. Food Sci. Nutr. 28:1-30.

Phillips, R.L. and S. Goldweber. 1981. Stylar-end breakdown in 'Tahiti' lime. Fruit Crops Fact Sheet FC-54. Florida Coop. Ext. Serv., Inst. Food and Agr. Sci., Univ. of Florida, Gainesville.

Smoot, J.J. and R.H. Segall. 1963. Hot water as a postharvest control of mango anthracnose. Plant Dis. Rptr. 47(8):739-742.

Spalding, D.H. and W.F. Reeder. 1972. Postharvest disorders of mangos as affected by fungicides and heat treatments. Plant Dis. Rptr. 56(9):751-753. 